\title{
Loss of receptor activity-modifying protein 3 exacerbates cardiac hypertrophy and transition to heart failure in a sex- dependent manner
}

\author{
Cordelia J. Barrick ${ }^{\mathrm{a}}$, Patricia M. Lenhart ${ }^{\mathrm{a}}$, Ryan T. Dackor ${ }^{\mathrm{a}}$, Elizabeth Nagle ${ }^{\mathrm{a}}$, and Kathleen \\ M. Caron ${ }^{a,{ }^{*}}$ \\ aDepartment of Cell \& Molecular Physiology, The University of North Carolina, Chapel Hill, North \\ Carolina, USA 27599
}

\begin{abstract}
Sex differences exist in the hypertrophic response, cardiac remodeling, and transition to heart failure of hypertensive patients, and while some of these differences are likely influenced by estrogen, the genetic pathways downstream of estrogen that impact on cardioprotection have yet to be fully elucidated. We have previously shown that the cardioprotective effects of adrenomedullin (AM), an emerging clinical biomarker for cardiovascular disease severity, vary with sex in mouse models. AM signaling during cardiovascular stress is strongly modulated by receptor activitymodifying protein 3 (RAMP3) via its interaction with the $\mathrm{G}$ protein-coupled receptor calcitonin receptor-like receptor (CLR). Like $A M, R A M P 3$ expression is potently regulated by estrogen, and so we sought to determine the consequences of genetic Ramp 3 loss on cardiac adaptation to chronic hypertension, with a particular focus on characterizing potential sex differences. We generated and bred $R A M P 3^{-1-}$ mice to RenTgMK mice that consistently display severe angiotensin II-mediated CV disease and compared CV disease progression in RenTgMK to that of RenTgMK:RAMP3 $3^{-1}$ offspring. As expected, RAMP3 gene expression was higher in cardiovascular tissues of RenTgMK mice and more strongly up-regulated in female RenTgMK mice relative to wildtype controls. RAMP3 loss did not affect the development of hypertension or the presence and severity of perivascular and interstitial fibrosis in the left ventricle (LV).

However, echocardiography revealed that while RenTgMK mice developed concentric cardiac hypertrophy with sustained systolic function, male RenTgMK:RAMP $3^{-1-}$ mice showed evidence of LV chamber dilatation and depressed systolic function, suggestive of cardiac decompensation. Consistent with these measures of heart failure, male RenTgMK:RAMP $3^{-1-}$ mice had increased cardiac apoptosis and elevated activation of Akt. These phenotypes were not present in female RenTgMK:RAMP3 ${ }^{-/-}$mice. Collectively, these data demonstrate a sex-dependant, cardioprotective role of RAMP3 in the setting of chronic hypertension.
\end{abstract}

\footnotetext{
(C) 2011 Elsevier Ltd. All rights reserved.

*Corresponding Author: Kathleen M. Caron, Department of Cell and Molecular Physiology, CB \# 7545, 6340B MBRB, 111 Mason Farm Road, The University of North Carolina at Chapel Hill, Chapel Hill, North Carolina 27599. Tel: (919) 966-5215, FAX: (919) 966-5230. Kathleen_caron@med.unc.edu.

Disclosures

None.

Publisher's Disclaimer: This is a PDF file of an unedited manuscript that has been accepted for publication. As a service to our customers we are providing this early version of the manuscript. The manuscript will undergo copyediting, typesetting, and review of the resulting proof before it is published in its final citable form. Please note that during the production process errors may be discovered which could affect the content, and all legal disclaimers that apply to the journal pertain.
} 


\section{Keywords}

adrenomedullin; receptor activity-modifying proteins; cardiovascular disease; sex differences; hypertension; heart failure

\section{Introduction}

Hypertension is a leading cause of cardiovascular disease morbidity and mortality. Cardiac hypertrophy, a compensatory response to chronic pressure overload, is seen in most individuals with chronic hypertension. However, significant sex differences exist in the hypertrophic response, cardiac remodeling, and transition to heart failure in hypertensive patients. For example, more rapid induction of hypertrophy occurs in men compared to women with similar degrees of elevated systolic pressure, while women show preserved cardiac function and ameliorated pathological remodeling compared to age-matched men with equivalent hypertension [1]. Premenopausal women have lower incidences of cardiovascular disease and related mortality than age-matched men, but this protection is lost with the onset of menopause. Evidence from clinical and experimental studies imply that a cardioprotective role of estrogen may impart sex differences in cardiac disease susceptibility [2-6]. However, recent results from the Women's Health Initiative found no reduction in CVD risk in postmenopausal women with hormone replacement therapy, suggesting that estrogen replacement alone is not sufficient to confer protection [7-9]. Therefore, identifying and understanding how genetic factors (particularly those which may be regulated by estrogen) interact and impact on estrogenic cardioprotection is an area of intense investigation [10-11].

An important estrogen-regulated cardioprotective factor is adrenomedullin (AM), a 52 amino acid, multifunctional peptide that circulates in the plasma in the low picomolar range. Numerous clinical studies have recently revealed that increased plasma levels of midregional pro-AM are highly correlated with and effectively predictive of poor clinical prognoses following myocardial infarction [12-15]. A potent vasodilator, AM is also directly cardioprotective, enhances cardiac contractility and is given clinically in some countries to counteract organ damage following myocardial infarction or to treat pulmonary hypertension [16-22]. While there is a great deal of interest and promise in using AM in the clinical setting, much remains unknown about how AM and its receptors confer cardioprotection.

AM receptors consist of an oligomeric complex between the GPCR calcitonin receptor-like receptor (gene: Calcrl, protein: CLR) and members of the receptor activity modifying protein (RAMP) family of chaperone proteins [23-24]. Currently, the RAMP family consists of three proteins (RAMPs 1-3) sharing a similar molecular mass (160 amino acids) and structure, but differing in sequence homology, tissue distribution, and requirement for normal embryonic development [25-27]. Any of the RAMPs can pair with CLR in the endoplasmic reticulum and transport it to the plasma membrane. However, association of CLR with RAMP2 or RAMP3 constitutes a receptor responsive to AM, while association of CLR with RAMP1 results in a receptor with affinity for another vasodilator, calcitonin gene related peptide. Several studies suggest that AM signaling during hypertension and other CV stress is strongly modulated by the RAMP3/CLR complex [28-30]. Since Ramp3 is robustly upregulated in the cardiovascular system in other models of hypertension [31-34] and may mediate CLR turnover [35-36], it has been postulated that RAMP3 is cardioprotective via altering AM signaling during CV stress. Recently, our laboratory generated RAMP3 null $\left(\right.$ Ramp $\left.^{-I-}\right)$ mice, which are viable and healthy with normal lifespans [25]. However, the 
physiological consequences of RAMP3 loss in hypertensive disease have not been directly examined.

A widely used experimental model of chronic hypertension and cardiac hypertrophy is the RenTgMK mouse. These mice have high and constant secretion of renin from the liver, elevated circulating levels of angiotensin II, and chronic hypertension [37-39]. Male RenTgMK have increased cardiac hypertrophy, pathological remodeling, and decreased survival compared to female RenTgMK mice or wild-type controls. We have previously shown that these sex differences diverge further with genetic loss of $A M$ [40]. RenTgMK $A M^{+/-}$male mice display increased cardiac hypertrophy and fibrosis compared to RenTgMK male mice with equivalent hypertension, however, these differences are not observed in female mice. Since, like AM, RAMP3 is potently induced by estrogen and contains functional estrogen receptor response elements in its promoter [41-42], we hypothesized that RAMP3 would be cardioprotective in the setting of chronic hypertension, but that this effect would be modulated by sex. To test this hypothesis, we bred RenTgMK to Ramp $3^{-1-}$ mice and compared sex-specific phenotypes in RenTgMK and RenTgMK;Ramp $3^{-/-}$ offspring.

\section{Materials and Methods}

\subsection{Animals}

Ramp3 null animals were generated as previously described [25] and crossed to heterozygous RenTgMK mice. PCR detection of the RenTgMK transgene and the null Ramp3 allele was performed using previously described primers [37, 39]. With the exception of longitudinal echocardiographies, all animals used in these studies were between 5-6 months of age and maintained on an isogenic 129S6/SvEv genetic background. Control animals were wild-type, age- and gender-matched littermates. All experiments were approved by the Institutional Animal Care and Use Committee of the University of North Carolina at Chapel Hill.

\subsection{Gene Expression Analysis}

Ramp3, Acadm/MCAD, and Nppa/ANP gene expression was analyzed by quantitative reverse transcription (RT)-PCR with the Mx3000P Q-PCR machine from Stratagene. Primer and probe sequences for detection of Ramp2, Ramp3, Adm and Calcrl gene expression were previously described [25, 43]. For all other primers and probes, we used a pre-designed, Assays on Demand primer/probe set (Applied Biosystems). Primer/probe sets for Gapdh (purchased from Applied Biosystems part \#4308313) or for Mouse eukaryotic translation elongation factor 1 alpha 1 (Primer sequences: 5'-CAGCAAAAATGACCCACCAATG-3' and 5'-TAAGCTCAGCAAACTTGCATGC-3', Probe sequence: 5'HEX GCT GGC TTC ACT GCT CAG GTG ATT ATC C-3'TAMRA) were used as internal controls for all samples. RNA was isolated from adult tissues with TRIzol reagent (Invitrogen) and subsequently DNase treated and purified with an RNeasy Mini kit (Qiagen). 1 ug of total RNA was used to generate cDNA using the High Capacity cDNA Archive kit (Applied Biosystems). The delta-delta $\mathrm{Ct}$ method was used to determine the relative levels of gene expression and shown as a fold increase over a whole embryo control.

\subsection{Measurement of basal blood pressure, heart rate, and urine chemistry}

Blood pressures and heart rates were measured on unanesthetized mice by a computerized tail cuff system [44]. Urinary concentration of sodium and potassium levels were measured through the UNC-CH Animal Clinical Chemistry Core Facility. 


\subsection{Histology}

For determining cardiac chamber to body weight ratios and wet lung weights, mice were weighed and hearts and lungs were dissected, rinsed in PBS, and weighed. The LV was cut in half along its axis, fixed in $4 \%$ paraformaldehyde and $5 \mu \mathrm{M}$ sections were prepared for subsequent staining for hemotoxylin and eosin (H\&E), Masson's Trichrome staining, anti- $\alpha-$ smooth muscle actin (anti- $\alpha$-SMA), or terminal deoxynucleotidyltransferase-mediated dUTP-digoxigenin nick end labeling (TUNEL) staining.

\subsection{Anti- $\alpha-S M A$ staining}

Paraffin sections were deparaffinized, rehydrated, rinsed in distilled $\mathrm{H}_{2} \mathrm{O}$ and permeabilized in $4 \%$ bovine serum albumin with $0.2 \%$ Triton X-100 in PBS. After being washed in PBS, specimens were incubated with $\alpha$-smooth muscle actin ( $\alpha$-SMA) (catalogue no. A2547; Sigma) antibody for $1 \mathrm{~h}$ at room temperature. Sections were then washed with PBS and PBS and incubated with a FITC -labeled donkey anti-mouse secondary antibody and DAPI for $120 \mathrm{~min}$ at room temperature. After being washed with PBS, the slides were mounted for imaging. Images were acquired on a Nikon FXA microscope and processed with Photoshop.

\subsection{TUNEL cell death assay}

Apoptotic cells were identified in 5- $\mu \mathrm{m}$ paraffin-embedded sections with the ApopTag Fluorescein In Situ apoptosis detection kit (Chemicon) according to the manufacturer's protocol. Images were acquired on a Nikon E800 microscope with a Hammamatsu ORCAER charge-coupled device camera with Metamorph software (Molecular Devices Corp.) and processed with Photoshop.

\subsection{Echocardiography}

Transthoracic echocardiography was performed with a 30-MHz probe and the Vevo 660 Ultrasonograph (VisualSonics). Mice were anesthetized with 1-1.5\% isoflurane. Heart rate (HR) was closely monitored and mice were placed under a heat lamp to maintain a constant body temperature of $37^{\circ} \mathrm{C}$. The heart was imaged in a two-dimensional parasternal long-axis view. An M-mode cursor was positioned perpendicular to the interventricular septum and the posterior wall of the left ventricle at the level of the papillary muscle. Measurements of left ventricular (LV) end diameter at diastole (LVED,d), LV end diameter at systole (LVED,s), LV posterior wall (PW) thickness at diastole (LVPW,d) and LVPW thickness at systole (LVPW,s) were taken and used to obtain calculated values of percent fractional shortening (\%FS), percent ejection fraction (\%EF), cardiac output (CO), and LV mass.

\subsection{Western Blotting}

Western blots were performed using whole mouse heart lysates. Samples were run on SDSPAGE gels and transferred to nitrocellulose membrane. Membranes were blocked for $1 \mathrm{~h}$ at room temperature in 5\% BSA in TBST and incubated with rabbit anti-pAKT (Cell Signaling \#4060S) or rabbit anti-pan AKT (Cell Signaling \#4691S) primary antibody in 5\% BSA in TBST overnight at $4^{\circ} \mathrm{C}$. Membranes were then washed in TBST, incubated with goat antirabbit 680 secondary antibody (Thermo Scientific \#35568) for $1 \mathrm{~h}$ at room temperature, and washed in TBST. Blots were imaged using LI-COR. Quantitation was performed with Image J.

\subsection{Statistical analysis}

Statistical analysis was performed by one-way analysis of variance followed by Fisher's PSLD using JMP software (SAS Institute, Cary, NC), and $p<0.05$ was considered significant. In all figures, error bars represent standard errors of the mean. 


\section{Results}

\subsection{Gene expression changes in response to loss of Ramp3 or Angll-induced cardiovascular disease}

To determine whether genetic deletion of Ramp3 alters expression of other members of the adrenomedullin signaling pathway, we analyzed expression of Rampl, Ramp2, and Calcrl in heart tissue of male and female Ramp3 $-/-$ mice compared to wild type controls. There was no change in Rampl or Ramp 2 gene expression in Ramp3 $-/-$ mice (Figure 1A,B), supporting our previous studies which demonstrate independent and non-overlapping functions of RAMP proteins. Calcrl expression was modestly, yet significantly, increased in Ramp3-/-hearts, but there were no differences between male and female mice (Figure 1C, Males: $\mathrm{p}<0.0002$, Females: $\mathrm{p}<0.05$ ). Therefore, we conclude that genetic loss of Ramp3 does not impact on the expression of other RAMP family members, but causes a modest compensation in Calcrl gene expression levels in the heart that is not distinguishable between males and females.

The expression of Ramp3 is consistently upregulated in rodent models of cardiac hypertrophy, hypertension and heart failure, leading to the hypothesis that increased AM signaling through RAMP3/CLR may be cardioprotective. However, sex differences in this response have not been examined. Therefore, we investigated changes in the expression of Ramp3 in male and female mice heterozygous for the genetically clamped renin transgene, RenTgMK. In this model of chronic hypertension, Ramp 3 gene expression was up-regulated in cardiovascular tissues (heart, kidney and lung) of RenTgMK mice of both sexes compared to wild-type littermates, with the greatest Ramp3 induction in the heart (Figure 1D). Since estrogen is known to robustly induce Ramp 3 expression [41-42], we expected and found that female RenTgMK mice had greater increases in Ramp3 gene expression in all cardiovascular tissues compared to male RenTgMK mice, with a nearly three-fold increase in cardiac Ramp3 expression.

\subsection{Loss of Ramp3 does not affect the development of chronic hypertension in mice over- expressing renin}

A single copy of the RenTgMK transgene elevates plasma renin levels and causes hypertension, cardiac hypertrophy, cardiovascular end-organ damage, and early death [37]. Consistent with previous reports, the RenTgMK transgene caused an increase in MAP of $\approx$ $40 \mathrm{mmHg}$ in male and female mice compared to wild-type controls ( $\mathrm{p}<0.01$; Table 1$)$. Although the loss of Ramp 3 moderately reduced the hypertension induced by the renin transgene, the RenTgMk;Ramp $3^{-/-}$animals remained significantly hypertensive compared to wildtype controls and there was no significant reduction in MAP compared to RenTgMK animals (Males: RenTgMk;Ramp $3^{-/}=126+/-7 \mathrm{mmHg}$, Females: RenTgMK;Ramp $3^{-/}=123+/-5 \mathrm{mmHg} ; \mathrm{P}=0.13$ and $\mathrm{P}=0.25$, respectively vs sex matched RenTgMK mice, Table 1). As previously reported [25], we again found no significant differences in MAP between Ramp $3^{-/-}$and wild-type mice (data not shown), and thus data was pooled. There was also no effect of Ramp3 loss on conscious heart rate (HR) (Table 1). Therefore, we conclude that genetic deletion of Ramp3 had no effect on the chronic hypertension that is induced by genetic over-expression of the RenTgMK transgene.

\subsection{Loss of RAMP3 exacerbates renal damage in male, but not female, mice with chronic hypertension}

Because RAMP3 is highly expressed in the proximal tubule of the kidney, we were interested in comparing hypertension-induced renal disease between RenTgMK;Ramp $3^{-/-}$ and RenTgMK mice. First, we evaluated the effect of RAMP3 on drinking behavior and urine production in the RenTgMK mice. Consistent with previous results, RenTgMK mice 
consumed significantly more water (both sexes, $p<0.05)$ and produced more urine (Males: $p$ 0.01; Females: $p<0.05$ ) of dilute osmolality (data not shown) compared to their WT counterparts (Supplemental Figures 1A and B). Although there were no differences by RAMP3 genotype in water intake (Males: RenTgMK=5.5 $\pm 0.4 \mathrm{ml}$ vs RenTgMK;Ramp $3^{-/}=5.9 \pm 0.3 \mathrm{ml}$; Females: RenTgMK $=4.9 \pm 0.3 \mathrm{ml}$ vs RenTgMK;Ramp $3^{-/-}=5.7 \pm 0.3$ ), urine production (Males: $\operatorname{RenTgMK}=2.9 \pm 0.4 \mathrm{ml}$, vs RenTgMK;Ramp $3^{-/}=2.7 \pm 0.5 \mathrm{ml}$; Females: RenTgMK $=2.3 \pm 0.4 \mathrm{ml}$ vs RenTgMK;Ramp $3^{-/-}=3.0 \pm 0.4 \mathrm{ml}$ ) or urine sodium or potassium levels (data not shown), gender differences emerged with respect to renal pathology. As shown in Figure 2A, the kidneys of all RenTgMK:Ramp $3^{-/}$male mice examined had severe glomerular sclerosis, interstitial and perivascular fibrosis, and greater incidence of proteinaceous casts as compared to male RenTgMK mice or female mice. Histological scoring of renal damage by trained observers blinded to genotype confirmed that RAMP3 loss did not influence renal damage in female mice, but significantly exacerbated renal disease in male mice $(p<0.05$, Figure 2B).

\subsection{Loss of RAMP3 exacerbates cardiac hypertrophy in male, but not female, mice with chronic hypertension}

To determine whether RAMP3 might impart sex-dependent cardioprotection on the heart, we further characterized the hearts of male and female mice that were either wild-type or homozygous null for RAMP3 and heterozygous for the RenTgMK transgene. Consistent with our previously published studies [25], there were no significant differences between RAMP3 null and wildtype animals in any parameter measured, and thus the results of Table 1 are presented as pooled WT data. Table 1 shows that RenTgMK and RenTgMK;Ramp $3^{-1-}$ mice developed cardiac hypertrophy as judged by an increase in left ventricle/body weight (LV:BW) ratio compared to age and sex matched controls ( $p<0.01$; Table 1). Interestingly, and similar to the sex-dependent effects on renal damage (Fig. 2B), loss of RAMP3 significantly increased both LV:BW and RV:BW ratio in male ( $p<0.05)$, but not female, mice on the RenTgMK background.

\subsection{Molecular phenotype of cardiac dysfunction resulting from RAMP3 loss}

To characterize the molecular phenotype of RenTgMK;Ramp $3^{-/-}$hearts, we next examined the expression of several markers indicative of cardiac hypertrophy and heart failure by quantitative RT-PCR using total RNA extracted from the left ventricle. We included genes recognized as markers of cardiac hypertrophy (atrial nautriuretic peptide- Nppa/ANP) and of cardiac metabolism (medium chain acyl dehydrogenase (Acadm/MCAD).

As expected and depicted in Figure 3A, Nppa/ANP expression was significantly associated with the RenTgMK genotype in both sexes (ANOVA, $p<0.01)$. Post-hoc analysis (Fisher's PSLD) revealed that ANP expression was significantly upregulated in the hearts of male, but not female, RenTgMK;Ramp $3^{-1-}$ mice compared to WT controls $(p<0.01)$. Since expression of ANP was highly and positively correlated with LV:BW $\left(r^{2}=0.88\right)$, it is not surprising that cardiac tissues of RenTgMK;Ramp $3^{-/-}$male mice exhibited the greatest induction of ANP.

Cardiac metabolism is profoundly altered in the failing heart, when cells switch their chief energy source from fatty acids to carbohydrates. A marker of this transition is the suppressed expression of MCAD. As depicted in Figure 3B, only male RenTgMK;Ramp $3^{-/-}$mice exhibited a significant decrease in MCAD expression compared to WT controls (Fisher's PSLD, $p<0.05)$. In addition, MCAD was inversely correlated with LV:BW in male $\left(r^{2}=\right.$ $-0.84)$, but not female $\left(r^{2}=-0.007\right)$, RenTgMK mice. Taken together, the molecular 
phenotype of RenTgMK;Ramp $3^{-/-}$male mice is consistent with exacerbated cardiac hypertrophy and suggestive of heart failure.

\subsection{Pathological changes in the hearts of RenTgMK;Ramp3 ${ }^{-/-}$mice}

Comparison of Masson's trichrome staining of the hearts of RenTgMK and

RenTgMK;Ramp $3^{-/-}$mice revealed gender differences in the degree of perivascular (PV) and interstitial (IS) fibrosis, with male mice more severely affected than female mice regardless of RAMP3 genotype (Figure 4A). Scoring for severity of fibrosis revealed that RenTgMK and RenTgMK:Ramp $3^{-1-}$ mice had similar degrees of fibrosis, independent of sex or genotype (Males: RenTgMK $=2.2+/-0.3(\mathrm{n}=6)$; RenTgMK:Ramp $3^{-/-}=1.5+/-0.4$ $(\mathrm{n}=4)$; Females: RenTgMK $=1.3+/-0.3(\mathrm{n}=9)$; RenTgMK:Ramp $3^{-/-}=1.1+/-0.3(\mathrm{n}=4)$ ).

Cardiomyocyte apoptosis leads to the progressive loss of contractile units and has been implicated in the pathogenesis of heart failure. Several studies in our lab and others have demonstrated the importance of AM-activated pro-survival signaling pathways in cardiomyocytes during development and under stress [17, 21-22, 45-46]. Staining for apoptotic cells in the hearts of 5 month old mice by TUNEL revealed apoptotic cells near the base of the heart, in the intraventricular septum and posterior LV wall (Figure 4B). Quantitation demonstrated a statistically significant 3-fold increase in apoptotic nuclei in the hearts of RenTgMK;Ramp $3^{-1-}$ male, but not female, mice compared to RenTgMK mice (Figure 4C).

\subsection{RAMP3 loss in male mice depresses cardiac function resulting in heart failure}

Concentric cardiac hypertrophy without dilatation or overt heart failure was previously reported in RenTgMK mice, with over half of male RenTgMK dying suddenly between 6-8 months of age accompanied by electrocardiographic abnormalities [37]. To determine if genetic loss of Ramp3 affected cardiac function in RenTgMK mice, we performed echocardiography on 5 month-old male and female animals. As shown in Table 2, RenTgMK mice displayed a phenotype similar to previous reports-- concentric or compensated hypertrophy, indicated by increased left ventricular wall thickness and sustained fractional shortening. Female RenTgMK;Ramp $3^{-1-}$ mice had a similar phenotype of concentric, compensated hypertrophy. However, male RenTgMK;Ramp $3^{-/-}$mice further displayed a significant increase in left ventricular end diastolic and systolic dimension, accompanied with depressed fractional shortening (\%FS). Representative B-Mode and Mmode tracings from male mice are shown in Figure 5A. These functional data demonstrate that male RenTgMK;Ramp $3^{-/-}$mice suffer from impaired cardiac contractility.

To determine whether loss of Ramp3 altered the life span of male RenTgMK mice, we aged RenTgMK;Ramp $3^{-/}$male mice beyond six months of age $(\mathrm{n}=7)$. We did not observe decreased survival among these mice compared to RenTgMK mice, indicating that despite the exacerbation of the RenTgMK phenotype, there did not appear to be any overall difference in survival rates in male RenTgMK;Ramp $3^{-1-}$ mice compared to male RenTgMK mice with intact Ramp3.

Further characterization of cardiac function at serial time points on the same animals revealed that male RenTgMK;Ramp $3^{-1-}$ mice had evidence of concentric cardiac hypertrophy by 3.5 months of age, and eventually developed progressive LV dilatation and systolic failure by 5 months of age (Figure 5B and 5C). These data demonstrate that loss of RAMP3 promoted decompensated hypertrophy and transition to heart failure, which was not evident in female RenTgMK;Ramp $3^{-1-}$ mice nor in male RenTgMK mice even at 8 months of age. 


\subsection{Loss of Ramp3 causes increased AKT activation in male, but not female, mice with chronic hypertension}

AKT signaling has emerged as a predominant pathway in the regulation of cardiomyocyte cell survival and apoptosis, and many of the functions of AM signaling have been attributed to this pathway $[17,20,22,46]$. Therefore, we evaluated AKT activation in male and female RenTgMK and RenTgMK;Ramp $3^{-1-}$ mice. Among male mice, AKT activation was increased in RenTgMK;Ramp $3^{-/-}$mice compared to RenTgMK mice with intact Ramp3 (Figure 6A, $\mathrm{p}<0.01$ ), and these data are consistent with the increase in apoptosis that was observed in male RenTgMK;Ramp $3^{-1-}$ mice. However, in female mice this increase in AKT activation was not observed (Figure 6B). In fact, RenTgMK;Ramp $3^{-/-}$female mice had a small but significant decrease in AKT activation compared to RenTgMK females (Figure $6 \mathrm{~B}, \mathrm{p}<0.02)$.

\subsection{Right ventricular hypertrophy in RenTgMK:Ramp3 ${ }^{-/-}$mice is not secondary to pulmonary pathology}

Few rodent models of hypertension also exhibit significant right ventricular hypertrophy (RVH), yet our analysis of RenTgMK;Ramp $3^{-1-}$ male mice revealed pronounced RVH (Table 1). Common causes of RVH include pulmonary congestion resulting from severe LV systolic failure and pulmonary arterial hypertension $(\mathrm{PAH})$; conditions that increase pulmonary resistance and RV work. Chronically elevated AngII levels, like those present in the RenTgMK model, are thought to promote pulmonary hypertension due to vasoconstrictor effects and pulmonary vasculature remodeling [47]. Numerous studies have shown that adrenomedullin, a canonical ligand for RAMP3-associated receptors, serves as a biomarker and therapeutic agent for PAH [48]. In addition, RAMP3 expression is strongly induced in the lungs under conditions of pulmonary stress such as sepsis and hypoxia [43, 49-50]. Therefore, we wondered whether genetic loss of Ramp3 might worsen pathological changes in the lungs, leading to the pronounced RVH observed in male RenTgMK;Ramp $3^{-1-}$ mice.

Although echocardiographic studies demonstrated that RenTgMK;Ramp $3^{-/-}$male mice developed LV failure, we did not see any differences in wet lung weights nor histological changes characteristic of pulmonary congestion compared to RenTgMK male mice (data not shown). One of the earliest changes in PAH is the muscularization of the terminal portion of the pulmonary arterial vascular tree, caused by hyperplasia of vascular smooth muscle cells. As revealed by Masson's trichrome staining and immunohistochemical staining for alpha smooth muscle actin, modest muscularization of terminal arterioles was observed in lungs of RenTgMK mice, however there was no difference in percent of muscularized arterioles or arteriolar wall thickness by Ramp3 genotype (Figure 7A and B). Together, these data lead us to conclude that the increased RVH observed in RenTgMK;Ramp $3^{-1-}$ male mice is not due to pulmonary congestion, PAH or other pathological changes in the lungs. Therefore, we conclude that RVH results from a primary effect of RAMP3 loss on cardiomyocytes in the setting of chronic hypertension.

\section{Discussion}

Within the RAMP family, RAMP3 has several unique features which argue for a protective role in cardiovascular disease. In the unstressed heart, RAMP3 is only detected at low levels, while RAMP2 is highly expressed [51-53]. However, numerous studies including our own, demonstrate that under conditions of CV stress, inflammation, hypoxia or oxidative stress, the expression of RAMP2 is markedly down-regulated with a concomitant and robust upregulation of RAMP3 gene expression [54]. The interaction of RAMP3, but not RAMP1 or RAMP2, with molecules involved in GPCR trafficking (NSF and NHERF) has led to the 
hypothesis that this dynamic "RAMP $2 / 3$ switch" may function as a protective mechanism by increasing CLR responsiveness to AM, or similarly, of other GPCRs to their cognate ligands. Ramp3 is also highly expressed in the kidney and Nowak et al. have shown that it plays an essential function for mediating the effects of AM on rat mesangial cells [55]. Finally, RAMP3 is one of the most potently estrogen-induced genes in mice and contains functional estrogen receptor response elements in its promoter. When these unique features of RAMP3 are considered in the context of our current findings, we conclude that there exist strong sexually dimorphic cardioprotective roles for RAMP3 during chronic hypertension, which may be further influenced by several, functionally-significant, genomic RAMP3 variants present in the human population [56].

We have previously used the RenTgMK model to reveal remarkably similar sex-dependent cardiovascular phenotypes in mice that lack one copy of the AM gene, RenTgMK; $A M^{+/-}$. Importantly, these two studies were performed on an identical isogenic genetic background, SvEv129/6, so that phenotypic comparisons between the cardiovascular responses of $\mathrm{AM}^{+/-}$ and Ramp $3^{-/-}$mice can be made. For both $A M^{+-}$and $R a m p 3^{-/-}$mice, we observed a worsening of cardiac hypertrophy and kidney damage, with no change in MAP or cardiac fibrosis, in male mice. Interestingly, female $\mathrm{AM}^{+/-}$and $\mathrm{Ramp}^{-/-}$mice were protected from these exacerbated cardiovascular pathologies, likely due to a shared sex-dependent signaling pathway, which can partially be attributed to increased expression of Calcrl in Ramp $3^{-/-}$ mice. Therefore, the modest, yet significant up-regulation of Calcrl gene expression in both male and female Ramp $3^{-1-}$ mice suggests that the function of RAMP3 is likely coordinated with overall levels of AM signaling.

Specific cardioprotective mechanisms downstream of AM/CLR/RAMP3 activation remain to be elucidated. Studies by Sexton and colleagues have shown that second messenger signaling and coupling of G proteins downstream of several GPCRs is influenced by association with RAMPs, implying that a CLR/RAMP3 complex may elicit a different intracellular second messenger response than a CLR/RAMP2 complex. It has been well established that exogenous AM is cardioprotective in acute CV stress (such as ischemiareperfusion injury) by activating AKT signaling and limiting apoptosis $[17,20,22,46]$ but it is not known if CLR/RAMP2 or CLR/RAMP3 complexes mediate this response. We found increased apoptosis and increased Akt activation in the hearts of male RenTgMK;Ramp $3^{-/-}$ mice, which were distinctly absent in the hearts of female RenTgMK;Ramp $3^{-/-}$mice. An association of high cardiac apoptosis and increased AKT signaling has been demonstrated by several other groups [57-58]. Our findings are consistent with these studies and further demonstrate an essential role for RAMP3 in regulating the PI3-kinase/AKT survival pathway in the heart. Future studies will investigate if the PI3-kinase/AKT survival pathway is differentially activated by AM/CLR/RAMP3 versus AM/CLR/RAMP2 complexes.

Since the RAMPs have a broader tissue distribution than CLR or its ligands, we and others hypothesized that additional GPCRs require the RAMPs for cellular trafficking and signaling [59-60]. Indeed, in the dozen years since RAMPs were discovered, calcitonin [61], vasoactive intestinal peptide/pituitary adenylate cyclase activating peptide 1, glucagon, parathyroid hormone 1 and 2 receptors [59], calcium sensing receptor [62] and secretin [63] have all been shown to partner with the RAMPs. Since RAMP3 can interact with many other members of family B GPCRs we cannot exclude the possibility that the observed cardioprotective effects of RAMP3, and their influence by sex, are mediated by other GPCRs beyond CLR. Because more than 50\% of all clinically available drugs target GPCRs, there is great interest in understanding pharmacological and biochemical properties of the RAMPs with the ultimate goal of manipulating the GPCR/RAMP interface for treatment of human disease. Ultimately, small molecule agonists targeting the GPCR/ RAMP3 interface may prove useful for gender-tailored therapies for heart failure. 


\section{Conclusions}

We have performed a comprehensive cardiovascular characterization of male and female Ramp $3^{-1-}$ mice in the context of angiotensin II-mediated hypertension. Consistent with previous studies identifying Ramp 3 as an estrogen-regulated gene, we found that Ramp3 gene expression is induced, particularly in the hearts of female mice, under conditions of cardiovascular stress. Genetic loss of RAMP3 did not affect the development of hypertension, however renal damage, cardiac hypertrophy and cardiac apoptosis were significantly exacerbated in male Ramp $3^{-/-}$mice carrying the RenTgMK transgene. Consequently, echocardiography studies revealed that male RenTgMK;Ramp $3^{-/-}$mice developed left ventricular dilatation, depressed systolic function, cardiac decompensation and increased AKT activation compared to female RenTgMK and RenTgMK;Ramp $3^{-1-}$ mice. Collectively, these data support a sexually dimorphic cardioprotective role of RAMP3 in the setting of chronic hypertension. The elucidation of pharmacologically-tractable GPCR pathways that are important in controlling the cardiovascular adaptation to chronic hypertension provides promise for future gender-tailored approaches for the treatment of heart failure.

\section{Supplementary Material}

Refer to Web version on PubMed Central for supplementary material.

\section{Acknowledgments}

This work was supported by an American Heart Association Established Investigator Award and a Burroughs Wellcome Fund Career Award in Biomedical Sciences to KMC.

\section{Abbreviations}

RAMP receptor activity modifying protein

AM adrenomedullin

CLR calcitonin receptor-like receptor

CV cardiovascular

GPCR G protein-coupled receptor

\section{References}

1. Regitz-Zagrosek V, Lehmkuhl E. Heart failure and its treatment in women. Role of hypertension, diabetes, and estrogen. Herz. 2005 Aug; 30(5):356-67. [PubMed: 16132238]

2. Babiker FA, Lips D, Meyer R, Delvaux E, Zandberg P, Janssen B, et al. Estrogen receptor beta protects the murine heart against left ventricular hypertrophy. Arterioscler Thromb Vasc Biol. 2006 Jul; 26(7):1524-30. [PubMed: 16627800]

3. Huang A, Kaley G. Gender-specific regulation of cardiovascular function: estrogen as key player. Microcirculation. 2004 Jan-Feb; 11(1):9-38. [PubMed: 15280095]

4. Patten RD, Pourati I, Aronovitz MJ, Baur J, Celestin F, Chen X, et al. 17beta-estradiol reduces cardiomyocyte apoptosis in vivo and in vitro via activation of phospho-inositide-3 kinase/Akt signaling. Circ Res. 2004 Oct 1; 95(7):692-9. [PubMed: 15345655]

5. Satoh M, Matter CM, Ogita H, Takeshita K, Wang CY, Dorn GW 2nd, et al. Inhibition of apoptosisregulated signaling kinase- 1 and prevention of congestive heart failure by estrogen. Circulation. 2007 Jun 26; 115(25):3197-204. [PubMed: 17562954] 
6. Skavdahl M, Steenbergen C, Clark J, Myers P, Demianenko T, Mao L, et al. Estrogen receptor-beta mediates male-female differences in the development of pressure overload hypertrophy. Am J Physiol Heart Circ Physiol. 2005 Feb; 288(2):H469-76. [PubMed: 15374829]

7. Hsia J, Criqui MH, Herrington DM, Manson JE, Wu L, Heckbert SR, et al. Conjugated equine estrogens and peripheral arterial disease risk: the Women's Health Initiative. Am Heart J. 2006 Jul; 152(1):170-6. [PubMed: 16824852]

8. Miller VM, Black DM, Brinton EA, Budoff MJ, Cedars MI, Hodis HN, et al. Using basic science to design a clinical trial: baseline characteristics of women enrolled in the Kronos Early Estrogen Prevention Study (KEEPS). J Cardiovasc Transl Res. 2009 Sep; 2(3):228-39. [PubMed: 19668346]

9. Rossouw JE, Anderson GL, Prentice RL, LaCroix AZ, Kooperberg C, Stefanick ML, et al. Risks and benefits of estrogen plus progestin in healthy postmenopausal women: principal results From the Women's Health Initiative randomized controlled trial. Jama. 2002 Jul 17; 288(3):321-33. [PubMed: 12117397]

10. Murphy E, Lagranha C, Deschamps A, Kohr M, Nguyen T, Wong R, et al. Mechanism of cardioprotection: what can we learn from females? Pediatr Cardiol. 2011 Mar; 32(3):354-9. [PubMed: 21279340]

11. Yang XP, Reckelhoff JF. Estrogen, hormonal replacement therapy and cardiovascular disease. Curr Opin Nephrol Hypertens. 2011 Mar; 20(2):133-8. [PubMed: 21178615]

12. Adlbrecht C, Hulsmann M, Strunk G, Berger R, Mortl D, Struck J, et al. Prognostic value of plasma midregional pro-adrenomedullin and C-terminal-pro-endothelin-1 in chronic heart failure outpatients. Eur J Heart Fail. 2009 Apr; 11(4):361-6. [PubMed: 19190023]

13. Al-Omari MA, Khaleghi M, Mosley TH Jr, Turner ST, Morgenthaler NG, Struck J, et al. Midregional pro-adrenomedullin is associated with pulse pressure, left ventricular mass, and albuminuria in African Americans with hypertension. Am J Hypertens. 2009 Aug; 22(8):860-6. [PubMed: 19424162]

14. Khan SQ, O'Brien RJ, Struck J, Quinn P, Morgenthaler N, Squire I, et al. Prognostic value of midregional pro-adrenomedullin in patients with acute myocardial infarction: the LAMP (Leicester Acute Myocardial Infarction Peptide) study. J Am Coll Cardiol. 2007 Apr 10; 49(14): 1525-32. [PubMed: 17418290]

15. von Haehling S, Filippatos GS, Papassotiriou J, Cicoira M, Jankowska EA, Doehner W, et al. Midregional pro-adrenomedullin as a novel predictor of mortality in patients with chronic heart failure. Eur J Heart Fail. 2010 May; 12(5):484-91. [PubMed: 20215339]

16. Ishimitsu T, Ono H, Minami J, Matsuoka H. Pathophysiologic and therapeutic implications of adrenomedullin in cardiovascular disorders. Pharmacol Ther. 2006 Sep; 111(3):909-27. [PubMed: 16616959]

17. Kato K, Yin H, Agata J, Yoshida H, Chao L, Chao J. Adrenomedullin gene delivery attenuates myocardial infarction and apoptosis after ischemia and reperfusion. Am J Physiol Heart Circ Physiol. 2003 Oct; 285(4):H1506-14. [PubMed: 12805025]

18. Nagaya N, Satoh T, Nishikimi T, Uematsu M, Furuichi S, Sakamaki F, et al. Hemodynamic, renal, and hormonal effects of adrenomedullin infusion in patients with congestive heart failure. Circulation. 2000 Feb 8; 101(5):498-503. [PubMed: 10662746]

19. Nishikimi T, Matsuoka H. Cardiac adrenomedullin: its role in cardiac hypertrophy and heart failure. Curr Med Chem Cardiovasc Hematol Agents. 2005 Jul; 3(3):231-42. [PubMed: 15974887]

20. Okumura H, Nagaya N, Kangawa K. Adrenomedullin infusion during ischemia/reperfusion attenuates left ventricular remodeling and myocardial fibrosis in rats. Hypertens Res. 2003 Feb; 26(Suppl):S99-104. [PubMed: 12630818]

21. Tokudome T, Horio T, Yoshihara F, Suga S, Kawano Y, Kohno M, et al. Adrenomedullin inhibits doxorubicin-induced cultured rat cardiac myocyte apoptosis via a cAMP-dependent mechanism. Endocrinology. 2002 Sep; 143(9):3515-21. [PubMed: 12193565]

22. Yin H, Chao L, Chao J. Adrenomedullin protects against myocardial apoptosis after ischemia/ reperfusion through activation of Akt-GSK signaling. Hypertension. 2004 Jan; 43(1):109-16. [PubMed: 14662648] 
23. McLatchie LM, Fraser NJ, Main MJ, Wise A, Brown J, Thompson N, et al. RAMPs regulate the transport and ligand specificity of the calcitonin-receptor-like receptor. Nature. 1998; 393(6683): 333-9. [PubMed: 9620797]

24. Morfis M, Christopoulos A, Sexton PM. RAMPs: 5 years on, where to now? Trends Pharmacol Sci. 2003 Nov; 24(11):596-601. [PubMed: 14607083]

25. Dackor R, Fritz-Six K, Smithies O, Caron K. Receptor activity-modifying proteins 2 and 3 have distinct physiological functions from embryogenesis to old age. J Biol Chem. 2007 Jun 22; 282(25):18094-9. [PubMed: 17470425]

26. Fritz-Six KL, Dunworth WP, Li M, Caron KM. Adrenomedullin signaling is necessary for murine lymphatic vascular development. J Clin Invest. 2008 Jan; 118(1):40-50. [PubMed: 18097475]

27. Wootten DL, Simms J, Hay DL, Christopoulos A, Sexton PM. Receptor activity modifying proteins and their potential as drug targets. Prog Mol Biol Transl Sci. 2010; 91:53-79. [PubMed: 20691959]

28. Cueille C, Pidoux E, de Vernejoul MC, Ventura-Clapier R, Garel JM. Increased myocardial expression of RAMP1 and RAMP3 in rats with chronic heart failure. Biochem Biophys Res Commun. 2002 Jun 7; 294(2):340-6. [PubMed: 12051717]

29. Oie E, Vinge LE, Andersen GO, Yndestad A, Krobert KA, Sandberg C, et al. RAMP2 and RAMP3 mRNA levels are increased in failing rat cardiomyocytes and associated with increased responsiveness to adrenomedullin. J Mol Cell Cardiol. 2005 Jan; 38(1):145-51. [PubMed: 15623431]

30. Yoshihara F, Nishikimi T, Okano I, Hino J, Horio T, Tokudome T, et al. Upregulation of intracardiac adrenomedullin and its receptor system in rats with volume overload-induced cardiac hypertrophy. Regul Pept. 2005 Apr 15; 127(1-3):239-44. [PubMed: 15680493]

31. Nishikimi T, Tadokoro K, Mori Y, Wang X, Akimoto K, Yoshihara F, et al. Ventricular adrenomedullin system in the transition from LVH to heart failure in rats. Hypertension. 2003 Mar; 41(3):512-8. [PubMed: 12623952]

32. Pan Ch S, Jiang W, Wu Sh Y, Zhao J, Pang YZ, Tang Ch S, et al. Potentiated response to adrenomedullin in myocardia and aortas in spontaneously hypertensive rat. Basic Res Cardiol. 2006 May; 101(3):193-203. [PubMed: 16450076]

33. Tadokoro K, Nishikimi T, Mori Y, Wang X, Akimoto K, Matsuoka H. Altered gene expression of adrenomedullin and its receptor system and molecular forms of tissue adrenomedullin in left ventricular hypertrophy induced by malignant hypertension. Regul Pept. 2003 Apr 15; 112(1-3): 71-8. [PubMed: 12667627]

34. Zhao Y, Bell D, Smith LR, Zhao L, Devine AB, McHenry EM, et al. Differential expression of components of the cardiomyocyte adrenomedullin/intermedin receptor system following blood pressure reduction in nitric oxide-deficient hypertension. J Pharmacol Exp Ther. 2006 Mar; 316(3):1269-81. [PubMed: 16326922]

35. Bomberger JM, Parameswaran N, Hall CS, Aiyar N, Spielman WS. Novel function for receptor activity-modifying proteins (RAMPs) in post-endocytic receptor trafficking. J Biol Chem. 2005 Mar 11; 280(10):9297-307. [PubMed: 15613468]

36. Bomberger JM, Spielman WS, Hall CS, Weinman EJ, Parameswaran N. Receptor activitymodifying protein (RAMP) isoform-specific regulation of adrenomedullin receptor trafficking by NHERF-1. J Biol Chem. 2005 Jun 24; 280(25):23926-35. [PubMed: 15805108]

37. Caron KM, James LR, Kim HS, Knowles J, Uhlir R, Mao L, et al. Cardiac hypertrophy and sudden death in mice with a genetically clamped renin transgene. Proc Natl Acad Sci U S A. 2004 Mar 2; 101(9):3106-11. [PubMed: 14978280]

38. Caron KM, James LR, Kim HS, Morham SG, Sequeira Lopez ML, Gomez RA, et al. A genetically clamped renin transgene for the induction of hypertension. Proc Natl Acad Sci U S A. 2002 Jun 11; 99(12):8248-52. [PubMed: 12034874]

39. Caron KM, James LR, Lee G, Kim HS, Smithies O. Lifelong genetic minipumps. Physiol Genomics. 2005 Jan 20; 20(2):203-9. [PubMed: 15585607]

40. Caron K, Hagaman J, Nishikimi T, Kim HS, Smithies O. Adrenomedullin gene expression differences in mice do not affect blood pressure but modulate hypertension-induced pathology in males. Proc Natl Acad Sci U S A. 2007 Feb 27; 104(9):3420-5. [PubMed: 17360661] 
41. Hewitt SC, Collins J, Grissom S, Deroo B, Korach KS. Global uterine genomics in vivo: microarray evaluation of the estrogen receptor alpha-growth factor cross-talk mechanism. Mol Endocrinol. 2005 Mar; 19(3):657-68. [PubMed: 15528273]

42. Watanabe H, Takahashi E, Kobayashi M, Goto M, Krust A, Chambon P, et al. The estrogenresponsive adrenomedullin and receptor-modifying protein 3 gene identified by DNA microarray analysis are directly regulated by estrogen receptor. J Mol Endocrinol. 2006 Feb; 36(1):81-9. [PubMed: 16461929]

43. Dackor R, Caron K. Mice heterozygous for adrenomedullin exhibit a more extreme inflammatory response to endotoxin-induced septic shock. Peptides. 2007 Nov; 28(11):2164-70. [PubMed: 17889965]

44. Hagaman JR, John S, Xu L, Smithies O, Maeda N. An improved technique for tail-cuff blood pressure measurements with dark-tailed mice. Contemp Top Lab Anim Sci. 2005 Sep; 44(5):43-6. [PubMed: 16138782]

45. Dackor RT, Fritz-Six K, Dunworth WP, Gibbons CL, Smithies O, Caron KM. Hydrops fetalis, cardiovascular defects, and embryonic lethality in mice lacking the calcitonin receptor-like receptor gene. Mol Cell Biol. 2006 Apr; 26(7):2511-8. [PubMed: 16537897]

46. Okumura H, Nagaya N, Itoh T, Okano I, Hino J, Mori K, et al. Adrenomedullin infusion attenuates myocardial ischemia/reperfusion injury through the phosphatidylinositol 3-kinase/Akt-dependent pathway. Circulation. 2004 Jan 20; 109(2):242-8. [PubMed: 14691041]

47. DeMarco VG, Habibi J, Whaley-Connell AT, Schneider RI, Heller RL, Bosanquet JP, et al. Oxidative stress contributes to pulmonary hypertension in the transgenic (mRen2)27 rat. Am J Physiol Heart Circ Physiol. 2008 Jun; 294(6):H2659-68. [PubMed: 18424632]

48. Murakami S, Kimura H, Kangawa K, Nagaya N. Physiological significance and therapeutic potential of adrenomedullin in pulmonary hypertension. Cardiovasc Hematol Disord Drug Targets. 2006 Jun; 6(2):125-32. [PubMed: 16787197]

49. Ono Y, Okano I, Kojima M, Okada K, Kangawa K. Decreased gene expression of adrenomedullin receptor in mouse lungs during sepsis. Biochem Biophys Res Commun. 2000 Apr 29; 271(1):197202. [PubMed: 10777702]

50. Qing X, Svaren J, Keith IM. mRNA expression of novel CGRP1 receptors and their activitymodifying proteins in hypoxic rat lung. Am J Physiol Lung Cell Mol Physiol. 2001 Mar; 280(3):L547-54. [PubMed: 11159039]

51. Husmann K, Born W, Fischer JA, Muff R. Three receptor-activity-modifying proteins define calcitonin gene-related peptide or adrenomedullin selectivity of the mouse calcitonin-like receptor in COS-7 cells. Biochem Pharmacol. 2003 Dec 1; 66(11):2107-15. [PubMed: 14609735]

52. Husmann K, Sexton PM, Fischer JA, Born W. Mouse receptor-activity-modifying proteins 1, -2 and -3: amino acid sequence, expression and function. Mol Cell Endocrinol. 2000 Apr 25; 162(12):35-43. [PubMed: 10854696]

53. Nagae T, Mukoyama M, Sugawara A, Mori K, Yahata K, Kasahara M, et al. Rat receptor-activitymodifying proteins (RAMPs) for adrenomedullin/CGRP receptor: cloning and upregulation in obstructive nephropathy. Biochem Biophys Res Commun. 2000 Apr 2; 270(1):89-93. [PubMed: 10733909]

54. Gibbons C, Dackor R, Dunworth W, Fritz-Six K, Caron KM. Receptor Activity-Modifying Proteins: RAMPing up Adrenomedullin Signaling. Mol Endocrinol. 2007 Apr; 21(4):783-96. [PubMed: 17053041]

55. Nowak W, Parameswaran N, Hall CS, Aiyar N, Sparks HV, Spielman WS. Novel regulation of adrenomedullin receptor by PDGF: role of receptor activity modifying protein-3. Am J Physiol Cell Physiol. 2002 Jun; 282(6):C1322-31. [PubMed: 11997247]

56. Bailey RJ, Bradley JW, Poyner DR, Rathbone DL, Hay DL. Functional characterization of two human receptor activity-modifying protein 3 variants. Peptides. 2010 Apr; 31(4):579-84. [PubMed: 20034525]

57. Ananthakrishnan R, Moe GW, Goldenthal MJ, Marin-Garcia J. Akt signaling pathway in pacinginduced heart failure. Mol Cell Biochem. 2005 Jan; 268(1-2):103-10. [PubMed: 15724443] 
58. Nagoshi T, Matsui T, Aoyama T, Leri A, Anversa P, Li L, et al. PI3K rescues the detrimental effects of chronic Akt activation in the heart during ischemia/reperfusion injury. J Clin Invest. 2005 Aug; 115(8):2128-38. [PubMed: 16007268]

59. Christopoulos A, Christopoulos G, Morfis M, Udawela M, Laburthe M, Couvineau A, et al. Novel receptor partners and function of receptor activity-modifying proteins. J Biol Chem. 2003 Jan 31; 278(5):3293-7. [PubMed: 12446722]

60. Hay DL, Poyner DR, Sexton PM. GPCR modulation by RAMPs. Pharmacol Ther. 2006 Jan; 109(1-2):173-97. [PubMed: 16111761]

61. Christopoulos G, Perry KJ, Morfis M, Tilakaratne N, Gao Y, Fraser NJ, et al. Multiple amylin receptors arise from receptor activity-modifying protein interaction with the calcitonin receptor gene product. Mol Pharmacol. 1999 Jul; 56(1):235-42. [PubMed: 10385705]

62. Bouschet T, Martin S, Henley JM. Receptor-activity-modifying proteins are required for forward trafficking of the calcium-sensing receptor to the plasma membrane. J Cell Sci. 2005 Oct 15; 118(Pt 20):4709-20. [PubMed: 16188935]

63. Harikumar KG, Simms J, Christopoulos G, Sexton PM, Miller LJ. Molecular Basis of Association of Receptor Activity-Modifying Protein 3 with the Family B G Protein-Coupled Secretin Receptor. Biochemistry. 2009 Nov 13. 


\section{Research Highlights}

- RAMP3 is an estrogen-regulated GPCR modifier protein induced during CV disease.

- We bred Ramp3-/- and RenTgMK mice, a genetic model of AngII-mediated CV disease.

- Male, but not female, Ramp3-/-mice suffer cardiac hypertrophy and renal damage.

- Male Ramp3-/- mice develop LV dilatation and decompensated heart failure.

- We elucidate a pharmacologically-tractable pathway in sex-dependent CV adaptation. 

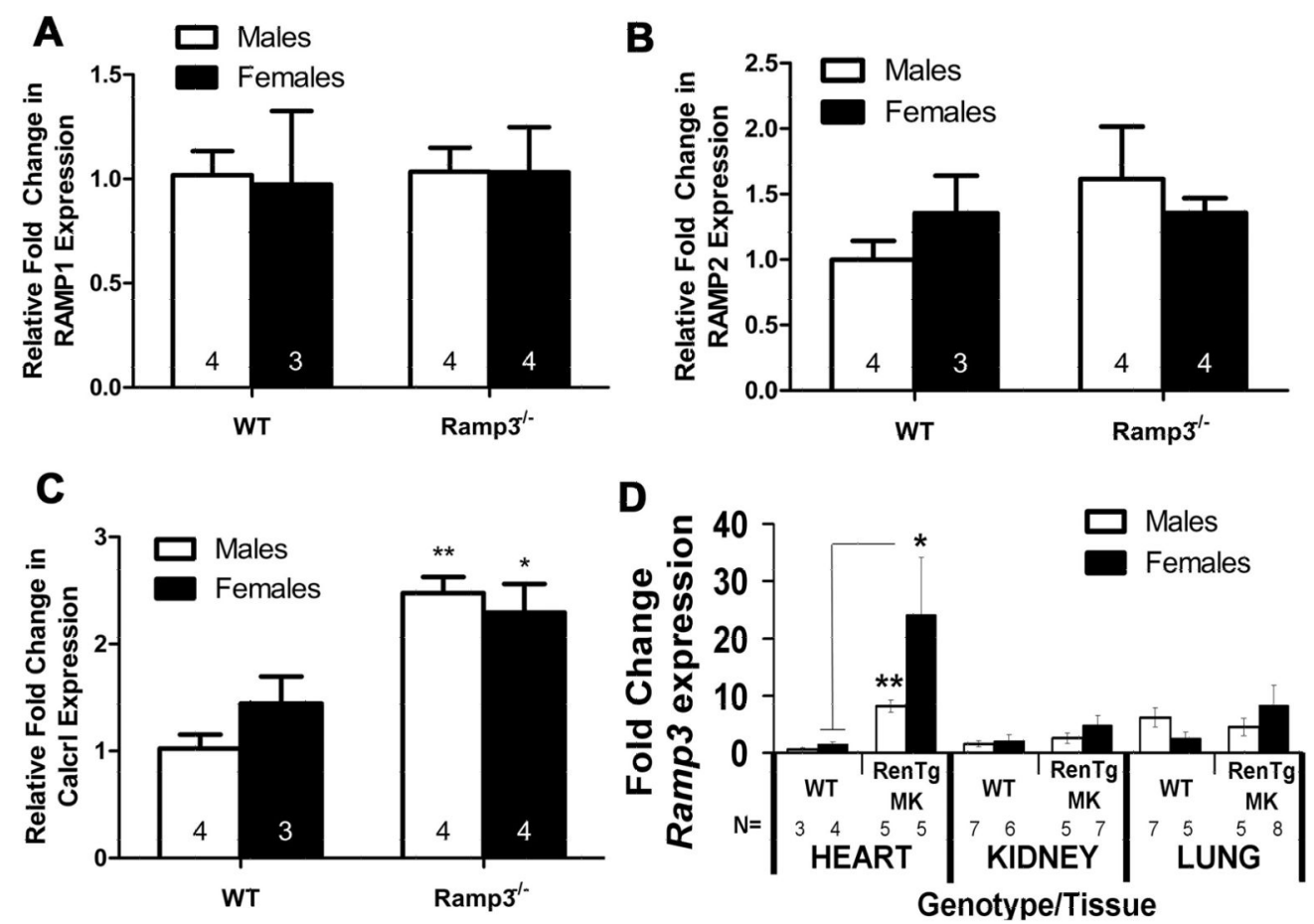

Figure 1.

Quantitative PCR was used to compare the expression of A) Ramp1, B) Ramp2 and C) Calcrl in hearts of Ramp3-/- mice. D) Ramp3 in CV tissues of WT and RenTgMK mice. The number of animals per genotype is depicted in the bars of the graphs. ${ }^{*} p<0.05$,

$* * p<0.01$ 

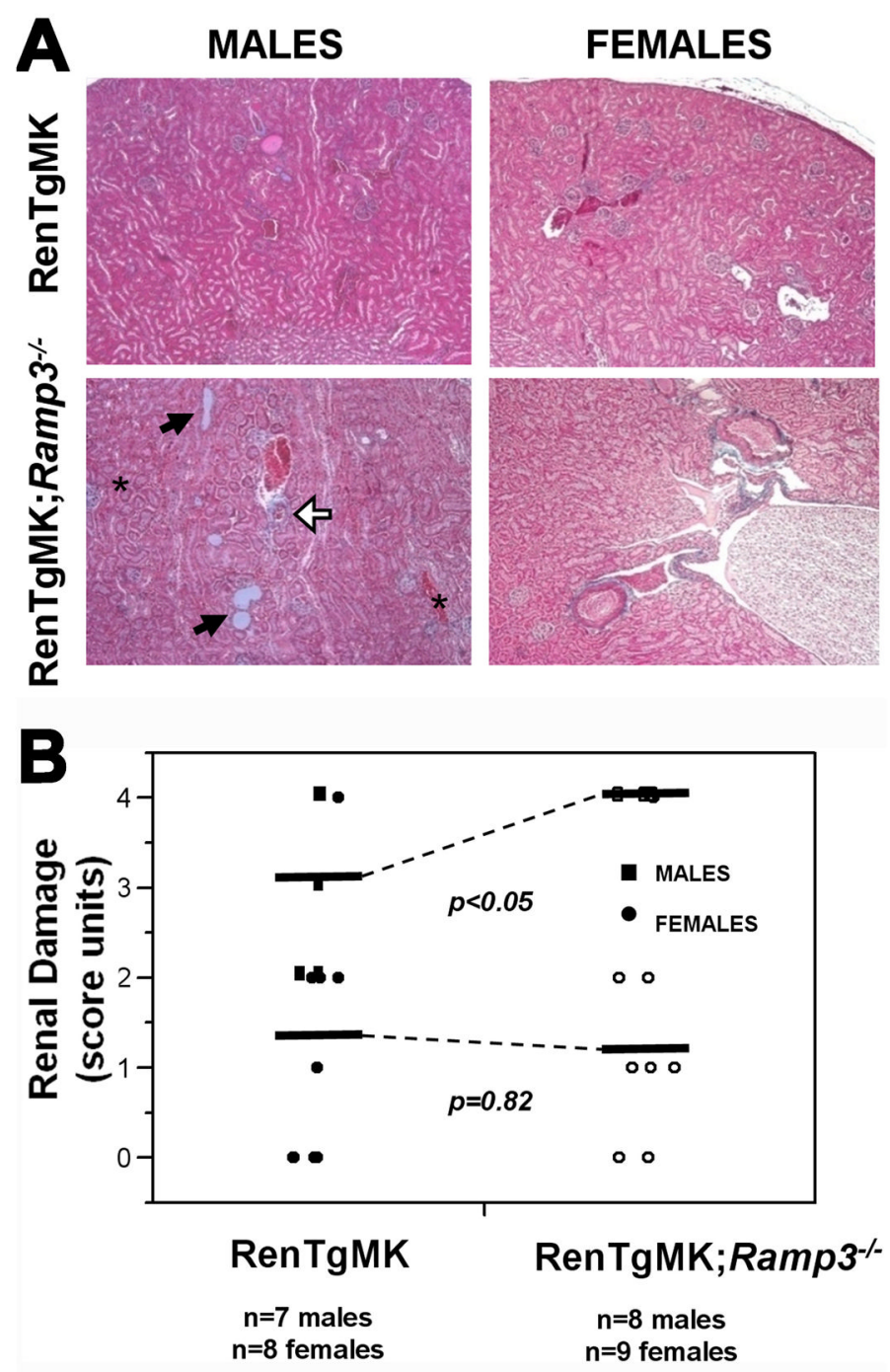

Figure 2.

Ramp $3^{-1-}$ male, but not female, mice suffer greater degree of renal damage in response to RenTgMK than wildtype mice. A) Representative Masson's trichrome stained sections showing kidney damage (proteinacous casts-black arrows; interstitial fibrosis-asteriks and perivascular fibrosis-open arrow) that is more severe in male RenTgMK;RAMP $3^{-1-}$ mice. B) Renal damage was scored using arbitrary units for the severity of glomerular sclerosis, vascular fibrosis, interstitial fibrosis and proteinaceous casts. 

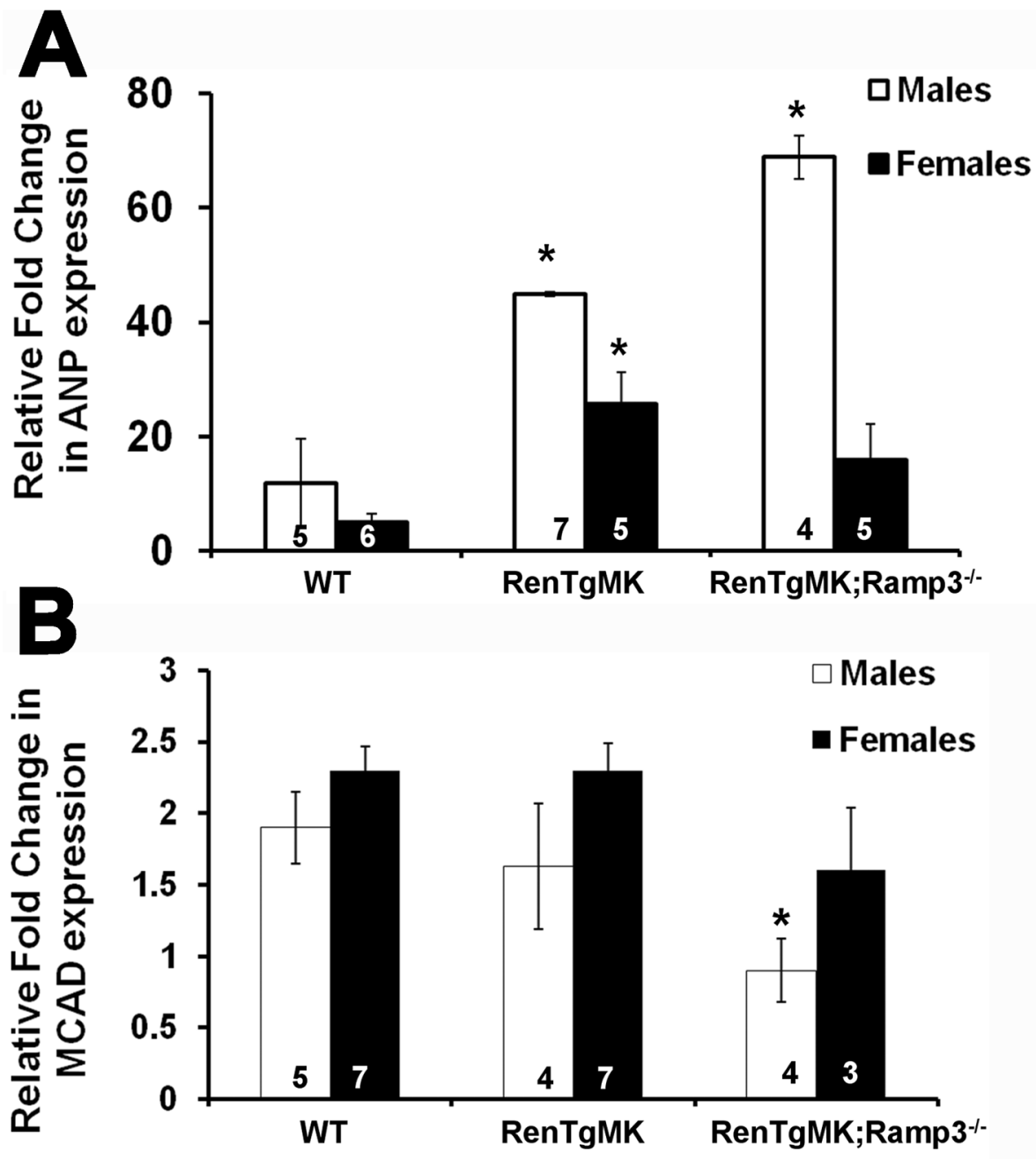

Figure 3.

Quantitative PCR was used to compare the expression of markers of hypertrophy and heart failure in the LVs of WT, RenTgMK and RenTgMK;Ramp $3^{-/-}$mice. The number of animals per genotype is depicted in the bars in each graph. (A) Nppa/ANP, ANP=atrial nautriuretic peptide. (B) Acadm/MCAD, MCAD= medium chain acyl dehydrogenase. $* p<0.05$ vs WT. 

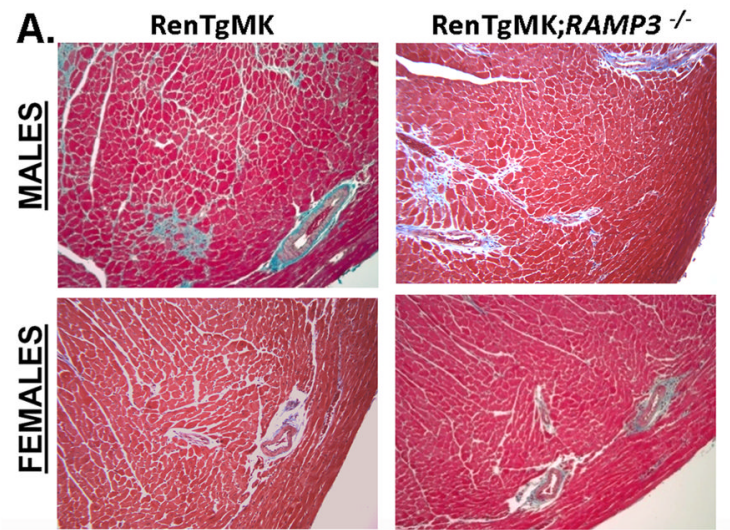

B.

RenTgMK
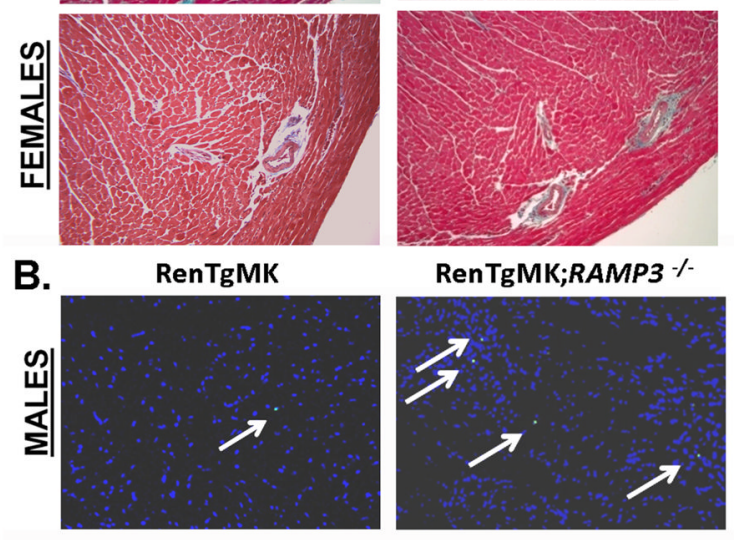

RenTgMK;RAMP3 $\%$

C.

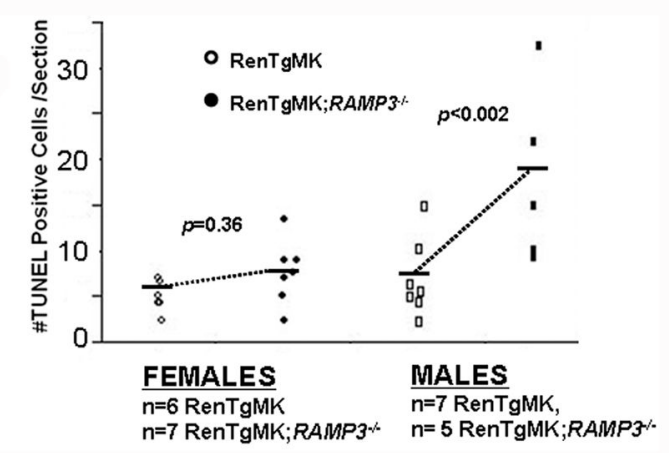

Figure 4.

Pathological changes in the hearts of RenTgMK;Ramp3-/-mice. A) Representative Masson's trichrome stained histological sections of the heart s of RenTgMK and RenTgMk;Ramp $3^{-/}$mice. B) Representative sections showing TUNEL-positive cardiac cells depicted by white arrows. C) Quantification of the number of TUNEL-positive cardiac cells from the hearts of RenTgMK and RenTgMK;Ramp $3^{-1-}$ male and female mice, revealing a statistically significant increase in male RenTgMK;Ramp $3^{-/-}$mice. 


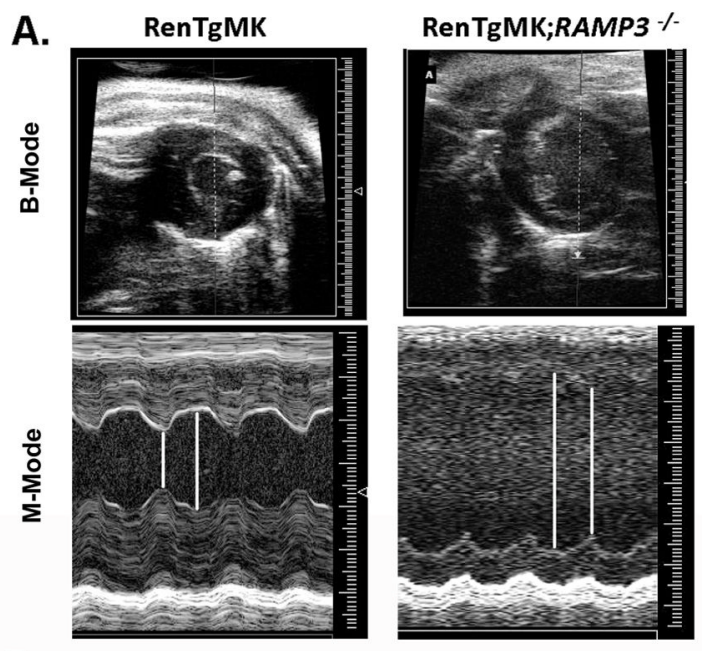

B.

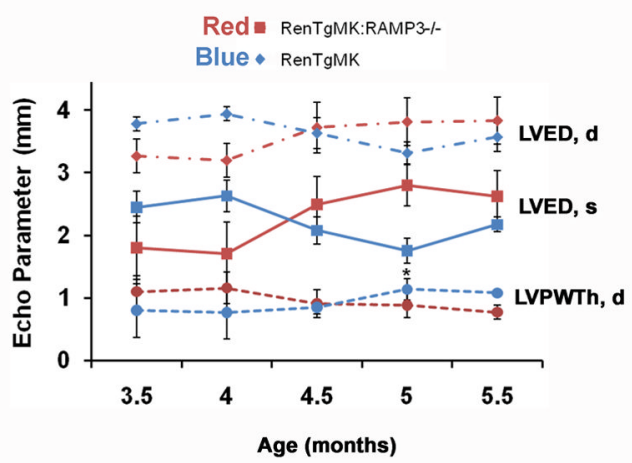

C.

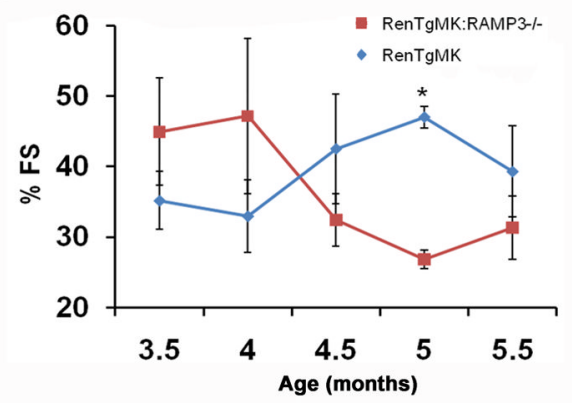

Figure 5.

A) Representative B mode images and corresponding M-mode tracings from RenTgMK and RenTgMK;Ramp3 $3^{-/-}$male mice. B) Serial echocardiography studies were performed in RenTgMK and RenTgMK;Ramp3 $3^{-/-}$male mice. Measured parameters are plotted over time in months. LVED,d=left ventricle end dimension, diastole; LVED,s=left ventricle end dimension, systole; LVPWTh,d=left ventricle posterior wall thickness, diastole; \% FS=percent fractional shortening. * $p<0.05$ vs RenTgMK;Ramp $3^{-/-}$. 

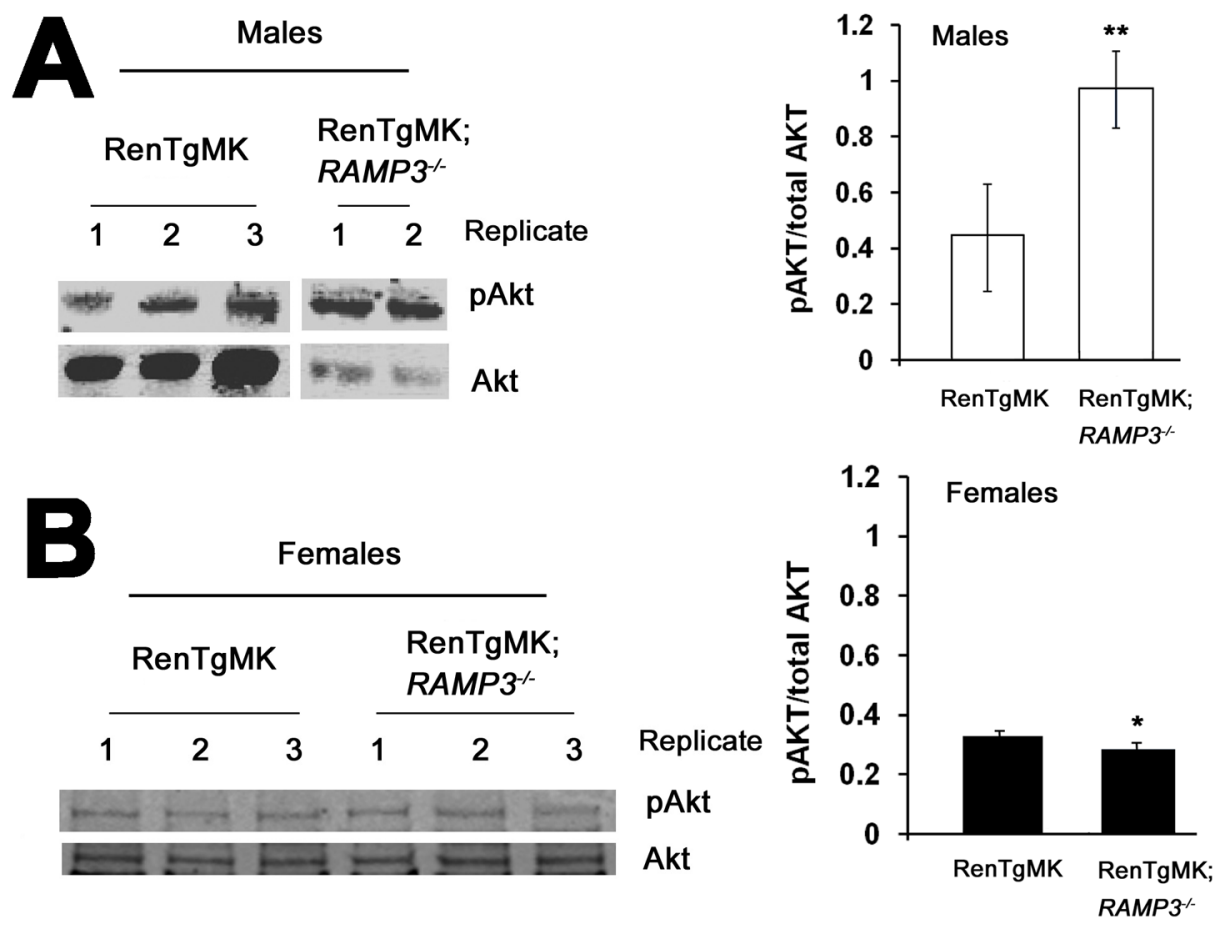

Figure 6.

Western blotting for AKT activation state in heart lysates from RenTgMK and RenTgMK;Ramp $3^{-/-}$mice. A) Representative AKT western blots and quantitation of male RenTgMK and RenTgMK;Ramp $3^{-/}$heart lysates. Samples were run on the same blot but middle lanes were removed from the image. ${ }^{*} p<0.01$ B) Representative AKT western blots and quantitation of female RenTgMK and RenTgMK;Ramp $3^{-/-}$heart lysates. ${ }^{*} p<0.02$ 


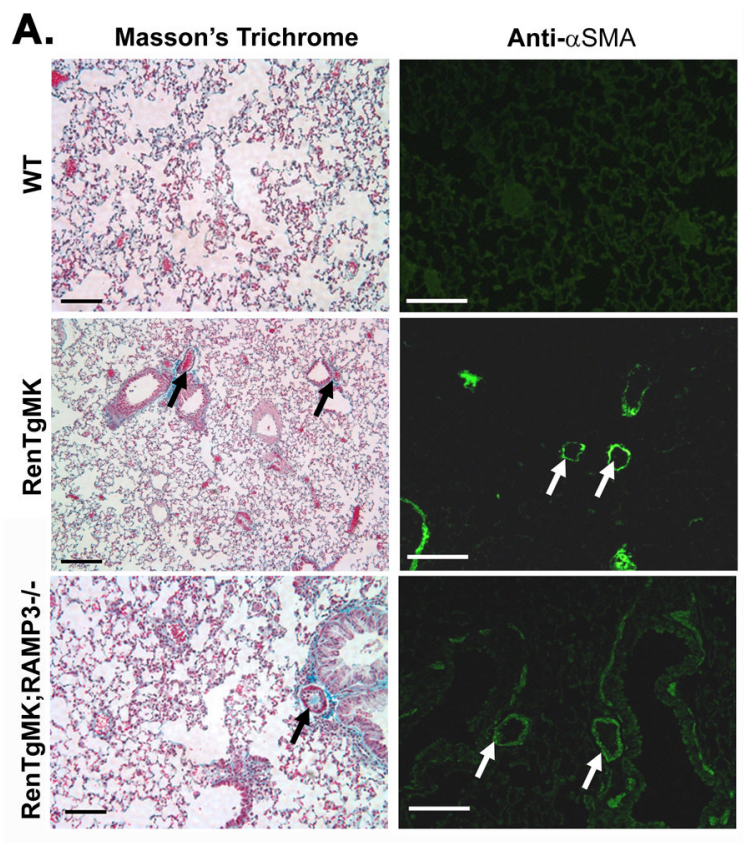

B.

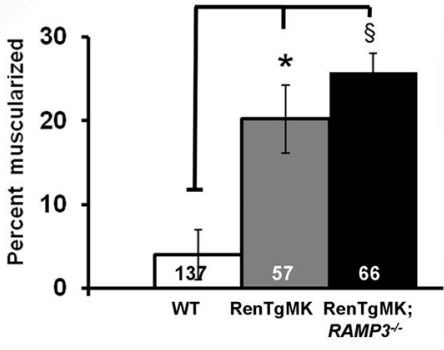

c.

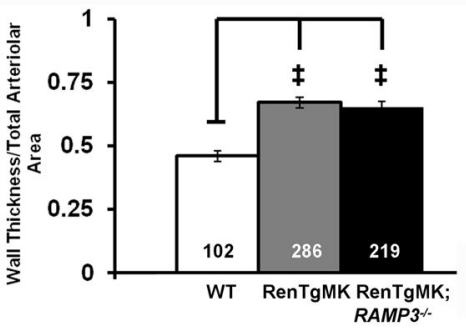

Figure 7.

Small pulmonary arteries (<100 um) of male RenTgMK and RenTgMK; $\operatorname{Ramp}^{-/-}$mice are muscularized. A) Representative sections of the lungs of WT, RenTgMK and

RenTgMK;Ramp3 $3^{-/-}$male mice stained with Masson's Trichrome or with FITC-conjugated anti-alpha smooth muscle actin ( $\alpha$ SMA). Scale bars:100 $\mu \mathrm{M} \mathrm{B})$ Percentage of muscularized small pulmonary arterioles in WT $(\mathrm{n}=135)$, RenTgMK $(\mathrm{n}=57)$, and RenTgMK;Ramp3 $3^{-/-}$ mice $(\mathrm{n}=66)(A N O V A, p<0.005)$. C) Total arteriole area, lumen area and wall thickness was measured in WT $(n=102)$, RenTgMK $(n=286)$ and RenTgMk;Ramp3 ${ }^{-/-}(n=210)$ arterioles. Results are summarized as the ratio of arteriolar wall thickness to total vessel area (ANOVA, $p<0.001$ ). 


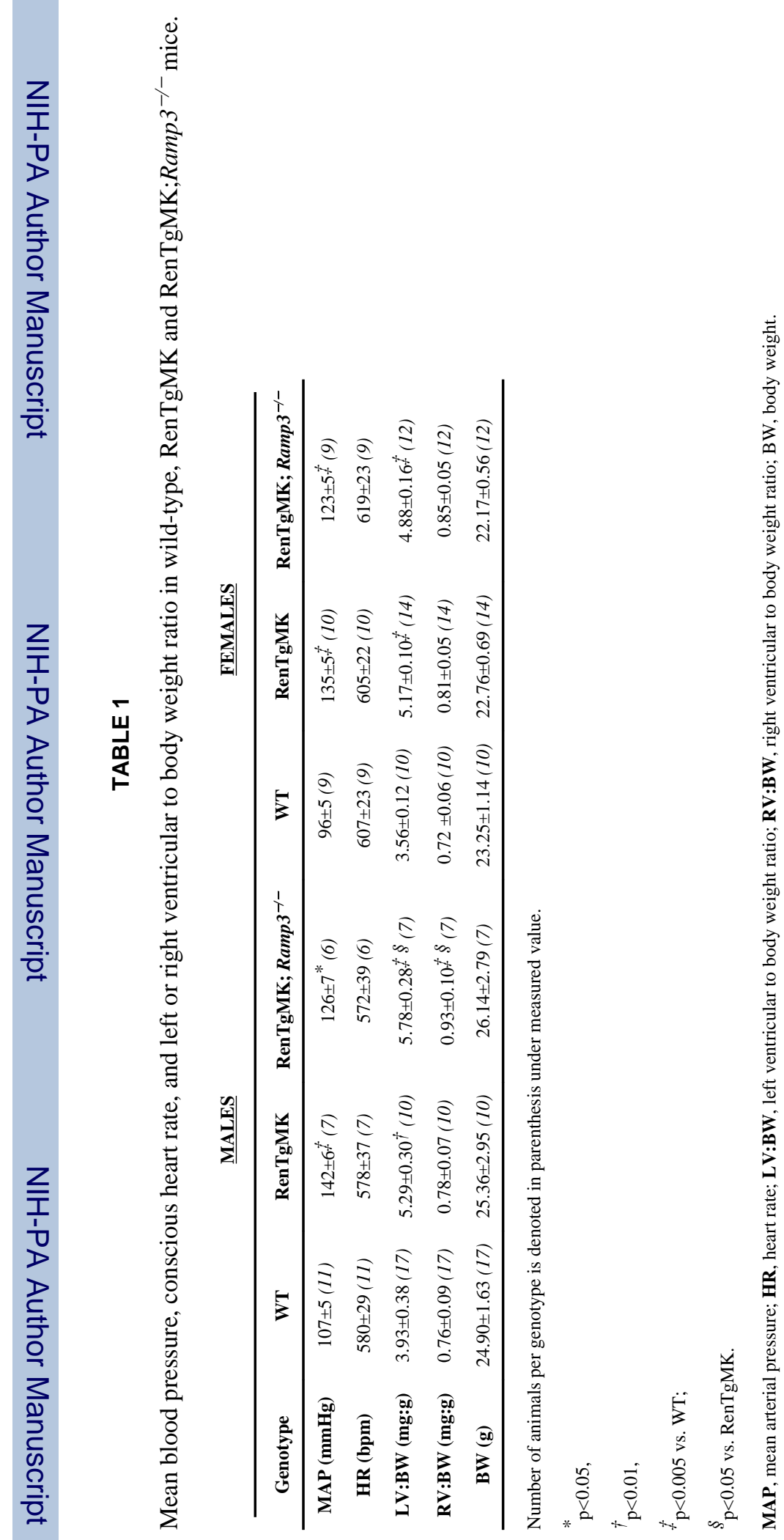

J Mol Cell Cardiol. Author manuscript; available in PMC 2013 January 1. 


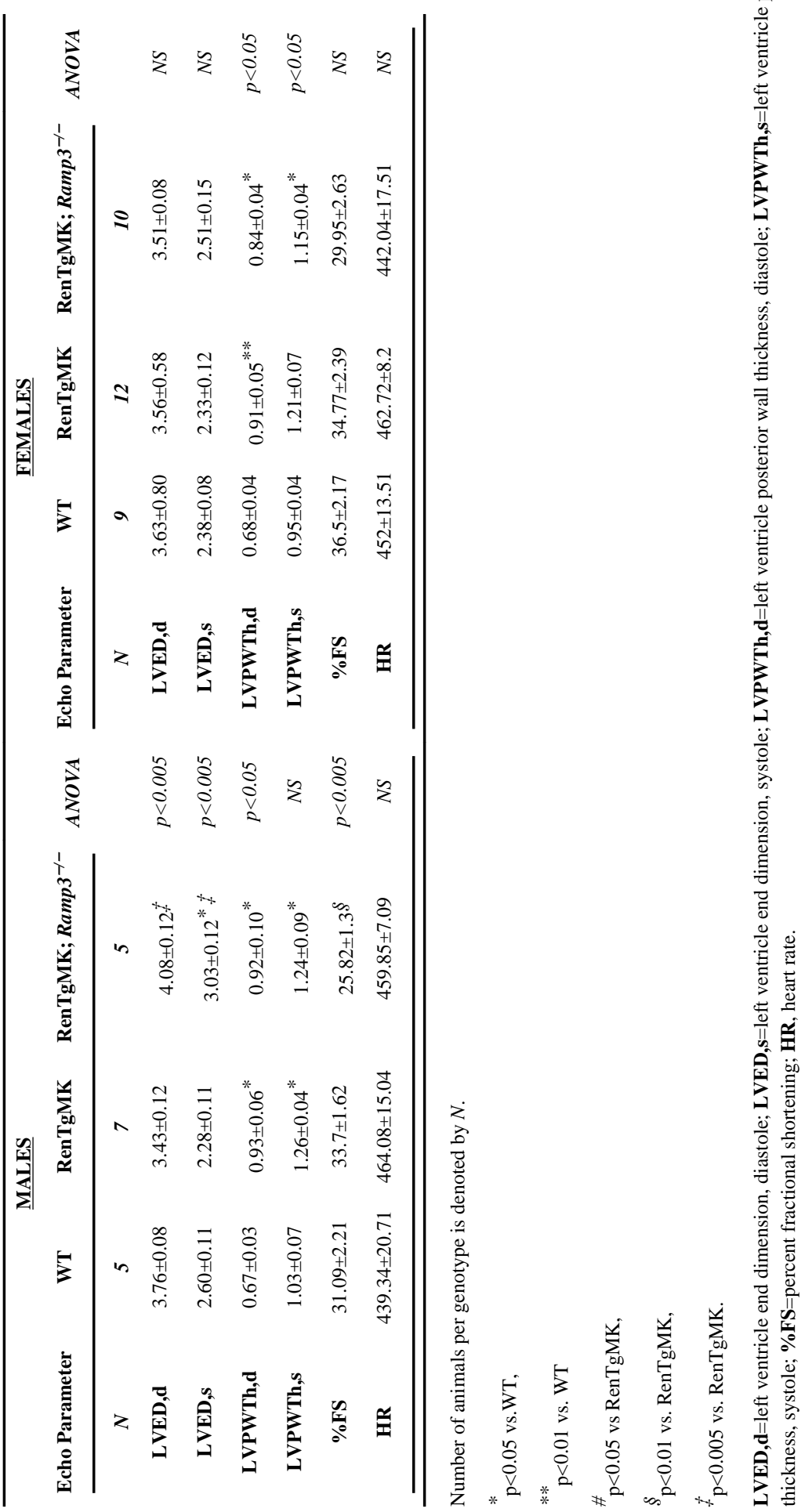

